\title{
Syntactic and Morphological Analysis of Portfolio Reports of Kindergarten Teachers in Surabaya, Indonesia
}

\author{
${ }^{1}$ Imelda Gozali and ${ }^{2}$ Faika Khairani \\ ${ }^{1,2}$ Widya Mandala Catholic University, Surabaya, Indonesia \\ ${ }^{1}$ Imelda.gozali@ukwms.ac.id \\ ${ }^{2}$ faikakhairani1710@gmail.com
}

Article History: Submitted August $13^{\text {th }}, 2021$; Accepted December $6^{\text {th }}, 2021$; Published December $14^{\text {th }}, 2021$

\begin{abstract}
As part of a community service project aimed at providing a customized English course to International Kindergarten teachers in Surabaya, Indonesia, this study investigated the types of grammatical (syntactic and morphological) errors made by the kindergarten teachers in the portfolio reports they wrote, and why the errors were committed. The data were taken from 9 (nine) portfolio reports of those teachers, and interview transcripts to three of them. The writers analyzed the errors using the Linguistic Category Taxonomy based on Dulay et al (1982) and categorized the reasons behind those errors into either Interlingual or Intralingual Errors (Richard, 1974). The result showed that Syntax - Noun Phrase type of error made up the biggest total number of errors (42\%), followed by Syntax Verb Phrase (31\%) and lastly, morphological - third-person singular incorrect (12\%). This study also found that the most frequent source of errors is Intralingual in nature (89\%). Overall, the results showed that any training aimed at those kindergarten teachers in particular, and in teacher training colleges in general, should address those most frequently committed errors. This Error Analysis on kindergarten teachers' portfolio reports is the first in this field and constitutes a valuable input for teacher training colleges of Early Childhood Education program.
\end{abstract}

Keywords: error analysis, interlingual error, intralingual error, kindergarten teachers, linguistic category taxonomy, portfolio reports,

Abstrak. Sebagai bagian dari kegiatan pengabdian pada masyarakat yang bertujuan untuk memberikan pelatihan Bahasa Inggris kepada guru-guru PAUD internasional di Surabaya, Indonesia, penelitian ini menyelidiki tipe-tipe kesalahan tata Bahasa (dari segi sintaks dan morfologi) yang dilakukan oleh guruguru PAUD dalam menulis rapor portofolio anak didik, dan juga mengapa kesalahan tersebut terjadi. Data diambil dari 9 (Sembilan) rapor portofolio para guru PAUD tersebut, beserta transkrip wawancara kepada tiga guru. Penulis menganalisis kesalahan tersebut dengan menggunakan Taksonomi Kategori Linguistik berdasarkan Dulay et al (1982). Sumber kesalahan tersebut dibagi ke Interlingual atau Intralingual, menurut Richard (1974). Hasil penelitian ini menemukan bahwa total kesalahan terbesar (42\%) terjadi pada bidang Sintaks yaitu pembentukan Noun Phrase, diikuti oleh bidang Sintaks juga yaitu pembentukan Verb Phrase (31\%), dan yang terkahir adalah bidang Morfologi yaitu kesalahan bentuk orang ketiga tunggal (12\%).Pada keseluruhan, hasil tersebut menunjukkan bahwa pelatihan Bahasa Inggris bagi para guru PAUD tersebut pada khususnya, maupun pada institusi keguruan pada umumnya, perlu memperhatikan aspek sintaks dan morfologi tersebut di atas. Error Analysis pada rapor portofolio ini baru pertama kali ini dilakukan, dan dapat memberi sumbangan berarti pada pengajaran Bahasa Inggris di institusi keguruan PAUD di Indonesia.

Kata kunci: analisis kesalahan, Bahasa Inggris, guru PAUD, kesalahan interlingual, kesalahan intralingual, rapor portofolio, taksonomi kategori linguistik 


\section{INTRODUCTION}

Laying the foundation of English literacy in children seems to be of utmost importance for many parents in Indonesia nowadays. This is proven by the proliferation of early childhood institutions offering bilingual (English - Indonesian) instruction, be them in formal or informal sectors throughout Indonesia. For the formal sector, we have the so-called 'international preschools', such as Apple Tree, Kinderland, Lollypop, Eton House, just to name a few. In terms of English courses, big names in the field like English First and IALF are also offering various programs for children.

With the mushrooming of the international preschools as described above, there is consequently a higher demand for PAUD (Pendidikan Anak Usia Dini, or Early Childhood Education) teachers who are highly proficient in English. Nevertheless, many teacher training colleges in Indonesia focus mainly on equipping the teacher trainees to teach in junior and senior high school, or only in grade school at best. Although many PAUD programs will have English subjects as their course prerequisite, the extent to which those subjects prepare the PAUD teacher trainees to speak and write in English in school is still uncertain (Wong \& Russak, 2020). Besides, some kindergartens might hire teachers not from Education nor English backgrounds (Masruroh, Ainiyah, \& Hidayah, 2018). All in all, the English capability of PAUD teachers in international preschools may not be as expected by the parents.

While many trainings in English have been conducted for PAUD teachers on speaking and vocabulary (Arif et al., 2021; Masruroh et al., 2018), hardly any has been given for English writing, which might be another problematic area for teachers of non-English background. In many international preschools, the teachers have to write what is known as "portfolio reports" for each student at the end of each term. This report describes the student's progress in the academic, social, and physical areas for the parents. To ensure that the reports are virtually free of grammatical or lexical errors, the school management might ask English consultants or experts to proofread the reports.

This study is part of a community service project in which the writers, in their capacity as English teachers and consultants, studied various portfolio reports of a certain international preschool in Surabaya, Indonesia. The reports were examined to find the kind of grammatical errors made by the kindergarten teachers in the portfolio reports and why they were committed. This study employed a document analysis design, with Error Analysis (Richards, 1971) as its methodology. In particular, Linguistic Category Taxonomy (Politzer \& Ramirez, 1973) was used to map out the errors. The reason behind the errors was then categorized between Interlingual and Intralingual Errors. The result of this study was then used to provide specific, custom-made English training for the teachers of this kindergarten. While conducting an Error Analysis on students' written works is common practice (Abdullah, 2013; Khan \& Khan, 2004; Wu \& Garza, 2014), a study on kindergarten teachers' portfolio reports might be the first of its kind and constitute a novelty in this field.

According to Corder (1973), errors are violations of a standard, which means they are against the grammatical rules of the language and result in unacceptable or ungrammatical utterances. In learning a second language, errors might occur because the learner has not internalized the grammar of the new language, which means the learner has not mastered the grammar yet. It can be said that errors occurred systematically when there is a lack of competence in the learner.

Errors are important to analyze since they will possibly give teachers or researchers some keys to the understanding of the process of learning the second language. Therefore, the teachers or researchers will find out what errors that learners usually commit and try to find out the causes. Richards (1971) 
stated that error analysis is an activity to reveal errors found in writing and speaking. Error analysis is defined as a technique for collecting, identifying, and classifying the mistake produced by someone in learning a second language, using any of the procedures provided by linguistics (Ellis, 2005).

Thus, it is necessary to state that although errors in learning a second language seem to be bad things, the analysis of errors is useful for both learners and teachers. To learners, error analysis is needed to show them which aspect that in grammar that difficult for them, whereas for teachers it is important to determine whether they are effective in teaching or not. Thus, error analysis should not be neglected in second language teaching.

Dulay (1982) classifies errors using four types of taxonomy: linguistic category taxonomy (Politzer and Ramirez, 1973), surface strategy taxonomy, comparative taxonomy, and communicative effect taxonomy. For this study, only Linguistic Category Taxonomy will be discussed. This taxonomy classifies errors according to either or both the language component or the particular linguistic constituent the errors affect (Dulay, 1982). Language components include phonology (pronunciation), syntax and morphology (grammar), semantics and lexicon (meaning and vocabulary), and discourse (style). In this study, and by the request of the stakeholders, the focus will be given more to morphology and syntax.

Lieber (2015, p.2) defines morphology as "the study of word formation." The error types of Morphology are indefinite article incorrect (e.g. missing the indefinite article ' $a$ ' in a sentence), possessive case incorrect (omission of the marker ('s) for possessive case), third-person singular verb incorrect (failure to attach $-\mathrm{s}$ in a third person singular verb in present tense), simple past tense incorrect (errors in the usage of regular and irregular past tense verb forms), past participle incorrect (omission of -ed in the passive form) and comparative adjective/adverb incorrect (the wrong use of 'er for comparative verb forms) (Politzer \& Ramirez, 1973)

The syntax is the part of Grammar that is concerned with how to word arrangement within a sentence conveys a particular meaning (Van Valin Jr., 2003). Syntax errors occur when the learner makes an error in the noun phrase, verb phrase, verb-and-verb construction, word order, and some transformations. Noun phrase errors comprise the use of determiners, nominalization, number, pronoun use, and preposition. Verb phrase errors constitute the omission of a verb, the use of progressive tense, and subject-verb agreement. There are four types of 'verb and verb construction errors', such as wrong use of past marker in the dependent verb (e.g., he was going to fell). Word order errors can be in the form of repetition of objects, or adjectival modifiers placed after the noun. Lastly, 'some transformation' errors include negative transformation, question transformation, 'there' transformation, and subordinate clause transformation (Politzer \& Ramirez, 1973).

Richards (1974) classified sources of errors into those deriving from the influence of the mother tongue or the first language of the learners, and these he termed Intralingual or Interference Errors. Secondly, there are also errors arising from the inherent difficulties of the target language itself, and this is what he called Intralingual Errors

Furthermore, Interference Errors occur as a result of the use of elements from one language while speaking another language. This type of error occurs as being the result of language transfer, which might be caused by the learners' mother tongue. As there are two types of transfer, namely positive and negative, it should be indicated here that this type of error is a result of the negative transfer of certain linguistic structures from L1, (Al-Khresheh, 2010). In other words, the negative transfer of 
the mother tongue or native language on learning the other language can be referred to as interlingual interference.

On the other hand, Intralingual Errors reflect the general characteristics of rule learning such as overgeneralizing a rule of the target language, ignorance of rule restrictions, incomplete application of the rule, and false concept hypothesized.

Error analysis on students' written works seems a fairly common practice. Wu and Garza (2014), on examining the errors made by Taiwanese $6^{\text {th }}$ graders in their email writing, concluded that more mistakes were made under the interlingual or transfer errors, as compared to the intralingual ones. It was further deduced that the intralingual errors were mainly due to overgeneralization and lack of exposure to the target language. Another study done in Malaysia was carried out by Abdullah (2013), who investigated the use of simple present and simple past tense among adult, TESL diploma students. He found out that most of the students made errors due to omission, addition, misinformation, and misordering. Similarly, Khan and Khan (2004) explored common errors made by 60 Saudi university students in their paragraph writing. They found that the most commonly committed errors are in the area of verb tense and form, subject-verb agreement, word order, prepositions, articles, auxiliaries, and spellings.

Error analyses on students' writing were also conducted in several schools and colleges in Indonesia. For example, Puspitasari (2013) studied grammatical errors made by second-semester students at Yogyakarta State University. The result of the analysis using the Linguistic Category shows that morphological and syntactic errors comprise a big number of errors in this study and the occurrence of syntactic error is higher than the morphological one. Similarly, Rohmah (2011) used Linguistic Category to study errors in interrogative sentences made by eight grade students. Based on the findings, he concluded that students produce a lot of errors in making interrogative sentences by omitting the auxiliary, errors in using auxiliary in yes/ no and WH question, and errors in using verb form. Mustafa et al (2016) made use of Surface Strategy Taxonomy, apart from the Linguistic Category Taxonomy, to study recount texts produced by 19 junior high school students. The results of data analysis showed that the dominant errors for surface strategy taxonomy were selection (72\%) followed by omission (14.4\%), and addition (10.6\%). In the linguistic category taxonomy, the most dominant types were word forms $(48.4 \%)$, followed by articles $(35 \%)$, nonfinite verbs $(34.9 \%)$, verb tenses (34.3\%), plurals (33.3\%), and prepositions (30\%). Lastly, Diani (2018) did research aimed at finding out the types of subject-verb agreement errors mostly made by college students of the English Education Study Program in Bandar Lampung. The result of data analysis showed that the error on the final $-\mathrm{s}$-es was $14 \%$. It was followed by the errors on singular and plural verb $(77 \%)$, and indefinite pronoun (9\%). In brief, the highest error made by the third-semester students of the English Department at UIN Raden Intan Lampung dealing with the subject-verb agreement was on singular and plural verb (77\%).

\section{METHOD}

This study is designed as qualitative research (McMillan \& Schumacher, 1993), using a document (error) analysis (Burns, 2015) as its primary methodology. The subjects of the study were 9 (nine) Kindergarten teachers in Surabaya who produced the portfolio reports. Permission has been obtained from the kindergarten in question to obtain several portfolio reports from those teachers and to interview some of them. The researchers themselves constitute the main instrument of this research, as they gathered the data, analyzed, and classified them. They were aided by semi-structured 
interview questions as to their instrument, to obtain a more in-depth insight on the reason behind the errors made by the teachers.

\section{Data Collection and Analysis}

The data were taken from 9 (nine) portfolio reports from nine kindergarten teachers, written in Term 1 of Academic Year 2019/2020. A sample of the portfolio report is shown in Appendix 1.

After identifying the morphological and syntactic errors committed in the reports, the writers tabulated the errors in a data analysis table, which was created based on the Linguistic Category Taxonomy (Dulay, 1982). This table (see Table 1) shows the erroneous sentences, type of errors, subtype of errors, frequency of errors and the corrections of the sentences, and the possible source of error. The writers asked two other validators to classify the errors, and the inter-rater reliability was computed (Glen, 2016). The resulting reliability (r) was 0.76 , which is considered acceptable. After being classified into the different types and sub-type of errors, the resulting number is computed as a percentage to find out the type of errors that most teachers committed.

To obtain deeper insight into the predicted source or cause of errors, three teachers were selected based on certain patterns in the errors they committed and were asked to be interviewed. Due to the COVID-19 pandemic, the interview had to be done using short questions via Google Form and clarified further using WhatsApp messages.

Table 1 Data Analysis

\begin{tabular}{|c|c|c|c|c|c|c|c|c|c|c|c|c|c|c|c|}
\hline \multirow[t]{2}{*}{ No. } & \multirow{2}{*}{$\begin{array}{c}\text { Sentences } \\
\text { Containing } \\
\text { Errors }\end{array}$} & \multirow[t]{2}{*}{ Corrections } & \multicolumn{11}{|c|}{ Types of Errors } & \multicolumn{2}{|c|}{$\begin{array}{c}\text { Possible Source of } \\
\text { Errors }\end{array}$} \\
\hline & & & A1 & $\mathrm{A} 2$ & A3 & A4 & A5 & A6 & B1 & B2 & B3 & B4 & B5 & $\begin{array}{l}\text { Interference } \\
\text { (Interlingual) }\end{array}$ & $\begin{array}{l}\text { Intra- } \\
\text { lingual }\end{array}$ \\
\hline \multicolumn{16}{|l|}{1.} \\
\hline \multicolumn{16}{|l|}{2.} \\
\hline \multicolumn{16}{|l|}{3.} \\
\hline \multicolumn{16}{|l|}{4.} \\
\hline \multicolumn{16}{|l|}{5.} \\
\hline \multicolumn{16}{|l|}{6.} \\
\hline \multicolumn{16}{|l|}{7.} \\
\hline \multirow{2}{*}{\multicolumn{3}{|c|}{ TOTAL }} & & & & & & & & & & & & & \\
\hline & & & & & & & & & & & & & & & \\
\hline
\end{tabular}

Description:

1. A1 $=$ Morphology - Indefinite article incorrect

2. $\mathrm{A} 2=$ Morphology - Possessive case incorrect

3. $\mathrm{A} 3=$ Morphology - Third person singular verb incorrect

4. A4 $=$ Morphology - Simple past tense incorrect

5. A5 $=$ Morphology - Past participle incorrect

6. A6 $=$ Morphology - Comparative adjective/ adverb incorrect

7. $\mathrm{B} 1=$ Syntax - Noun phrase

8. $\mathrm{B} 2=$ Syntax - Verb phrase

9. $\mathrm{B} 3=$ Syntax - Verb- and - verb construction

10. $\mathrm{B} 4=$ Syntax - Word order

11. $\mathrm{B} 5=$ Syntax - Some transformation 


\section{RESULTS AND DISCUSSION}

\section{Types of Error}

From the document analysis result, a total of 186 errors were found in the 9 (nine) portfolio reports. The errors were classified into the different linguistic categories and tabulated, the results of which are shown in Table 2.

Table 2 The Total Number and Percentage of Each Type of Errors

\begin{tabular}{llcc}
\hline \multirow{2}{*}{ No. } & Types of Error & \multicolumn{2}{c}{ Frequency } \\
\cline { 3 - 4 } & & $\mathrm{N}$ & $\%$ \\
\hline 1. & $\mathrm{~A} 1$ & 0 & $0 \%$ \\
\hline 2. & $\mathrm{~A} 2$ & 3 & $2 \%$ \\
\hline 3. & $\mathrm{~A} 3$ & 23 & $12 \%$ \\
\hline 4. & $\mathrm{~A} 4$ & 5 & $3 \%$ \\
\hline 5. & $\mathrm{~A} 5$ & 5 & $3 \%$ \\
\hline 6. & $\mathrm{~A} 6$ & 4 & $2 \%$ \\
\hline 7. & $\mathrm{~B} 1$ & 78 & $42 \%$ \\
\hline 8. & $\mathrm{~B} 2$ & 58 & $31 \%$ \\
\hline 9. & $\mathrm{~B} 3$ & 2 & $1 \%$ \\
\hline 10. & B & 0 & $0 \%$ \\
\hline 11. & B5 & 8 & $4 \%$ \\
\hline TOTAL & & 186 & $100 \%$ \\
\hline
\end{tabular}

As presented in Table 2, the highest frequency of errors happens in B1 (syntax - Noun phrase) which consists of seventy-eight errors or $42 \%$. In the second place, B2 (syntax - Verb phrase) consists of fifty-eight errors or 31\%. Then, A3 (morphology - Third-person singular verb incorrect) becomes the third type of error that is commonly produced in the portfolio report which consists of twenty-three errors or $12 \%$. Sample of errors belonging to the B1, B2, and A3 types are shown below.

As mentioned above, the B1 and B2 errors fall under the category of syntactic errors, with B1 indicating errors in the formation of Noun Phrase, and B2 for Verb Phrase.

\section{(B1) Noun Phrase}

\section{Determiners}

\begin{tabular}{lll}
\hline No. & Erroneous Sentence & Correction \\
\hline 5. & $\begin{array}{l}\text { She obeys the teachers and follows } \\
\text { (the) activities nicely. }\end{array}$ & $\begin{array}{l}\text { She obeys the teachers and follows the } \\
\text { activities nicely. }\end{array}$ \\
\hline
\end{tabular}

In sentence number 5, the noun activities seem to be missing a determiner of the article "the" which should be the activities.

\begin{tabular}{lll}
\multicolumn{2}{l}{ Nominalization } \\
\hline No. & Erroneous Sentence & Correction \\
\hline 49. & $\begin{array}{l}\text { Kimora needs to be reminded about } \\
\text { take (taking) turn and compassion. }\end{array}$ & $\begin{array}{l}\text { Kimora needs to be reminded about } \\
\text { taking turn and compassion. }\end{array}$ \\
\hline
\end{tabular}

The sentence above shows the phrase that comes after about should be a noun phrase, and so the verb form take should be nominalized as taking. 


\begin{tabular}{lll}
\hline Number & \\
\hline No. & Erroneous Sentence & Correction \\
\hline 27. & $\begin{array}{l}\text { He is also always curious about new } \\
\text { thing(s) we learn in the class. }\end{array}$ & $\begin{array}{l}\text { He is also always curious about new } \\
\text { things we learn in the class. }\end{array}$ \\
\hline
\end{tabular}

In the sentence above, the noun thing must be general, so it must be plural (and not just one specific thing)

\section{Use of pronouns}

\begin{tabular}{lll}
\hline No. & Erroneous Sentence & Correction \\
\hline 25. & $\begin{array}{l}\text { We are happy to have Nathan as one } \\
\text { of (our) N1 students. }\end{array}$ & $\begin{array}{l}\text { We are happy to have Nathan as one of } \\
\text { our N1 students. }\end{array}$ \\
\hline
\end{tabular}

The sentence above requires to use of pronouns our since the subject pronoun in this sentence is we.

\section{Use of prepositions}

\begin{tabular}{lll}
\hline No. & Erroneous Sentences & Correction \\
\hline 24. & $\begin{array}{l}\text { She struggles and tries harder, such as } \\
\text { (in) recognizing letters a-m, rote }\end{array}$ & $\begin{array}{l}\text { She struggles and tries harder, such as } \\
\text { in recognizing letters a-m, rote }\end{array}$ \\
& $\begin{array}{l}\text { counting from 1-10, and memorizing } \\
\text { the words during reading }\end{array}$ & $\begin{array}{l}\text { counting from 1-10, and memorizing } \\
\text { the words during reading }\end{array}$ \\
He shows curiosity about new things & He shows curiosity about new things \\
we learn at (in) the class. & we learn in the class. \\
\hline
\end{tabular}

In sentence number 24 , the teacher missed adding the preposition in.

In sentence number 46, the preposition of at is incorrect. It should use the preposition in in this context

\section{(B2) Verb Phrase}

\section{Omission of verb}

\begin{tabular}{lll}
\hline No. & Erroneous Sentence & Correction \\
\hline 4b. & $\begin{array}{l}\text { However, Joyce still speaks Bahasa and } \\
\text { (is) not too active during discussion. }\end{array}$ & $\begin{array}{l}\text { However, Joyce still speaks Bahasa } \\
\text { and is not too active during discussion. }\end{array}$ \\
\hline
\end{tabular}

The sentence above is incorrect because the teacher omitted the auxiliary verb $i s$.

\begin{tabular}{lll}
\multicolumn{2}{l}{ Agreement of subject and verb } \\
\hline No. & Erroneous Sentence & Correction \\
\hline 102. & It make(s) her friends follow to speak & $\begin{array}{l}\text { It makes her friends follow to speak } \\
\text { English also. }\end{array}$ \\
\hline
\end{tabular}

The sentence above is incorrect; it should be it makes not it make.

On the other hand, the A type of errors falls under morphological ones. In this case, the A3 type of error is the term "third-person singular incorrect", which constituted the third type of errors most committed by the teachers in this study. Samples of the A3 type of errors are shown below. 


\section{(A3) Third-person singular incorrect}

\section{Failure to attach $-S$}

\begin{tabular}{lll}
\hline No. & Erroneous Sentence & Correction \\
\hline 43. & $\begin{array}{l}\text { She enjoy(s) herself more when she } \\
\text { comes to school. }\end{array}$ & $\begin{array}{l}\text { She enjoys herself more when she } \\
\text { comes to school. }\end{array}$ \\
45. & $\begin{array}{l}\text { She tries to express her feeling even } \\
\text { though she still learn(s) how to } \\
\text { speak. }\end{array}$ & $\begin{array}{l}\text { She tries to express her feeling even } \\
\text { though she still learns how to speak. }\end{array}$ \\
\hline
\end{tabular}

In the sentence above, the teacher missed adding $-\mathrm{s}$ in the verb enjoy and learn which should be enjoys and learns because it is used for third-person singular.

\begin{tabular}{lll} 
Wrong attachment of $-\boldsymbol{s}$ & \\
\hline No. & Erroneous Sentence & Correction \\
\hline $92 \mathrm{~b}$. & $\begin{array}{l}\text { She is a good listener in the class who } \\
\text { is always able to listens (listen) }\end{array}$ & $\begin{array}{l}\text { She is a good listener in the class who } \\
\text { is always able to listen attentively }\end{array}$ \\
& $\begin{array}{l}\text { attentively during teachers' explanation, during teachers' explanation and is } \\
\text { and is able to answer teachers' } \\
\text { questions. }\end{array}$ & \\
\hline
\end{tabular}

The example of the wrong attachment of $-\mathrm{s}$ is the sentence $92 \mathrm{~b}, \ldots$ to listen attentively. In that sentence, the teacher added $-\mathrm{s}$ in the word listen. The correct form should be listen.

\section{Sources of Errors}

Based on the classification of the source of errors by Richard (1974), the 186 errors were classified into whether the cause appeared to be Interlingual (interference from the mother tongue) or intralingual (difficulties inherent in the language being studied, or developmental errors). The result of the classification is shown in Table 3.

Table 3 The Total Number and Percentage of the Sources of Errors

\begin{tabular}{lll}
\hline Possible Source of Errors & $\mathrm{N}$ & Percentage (\%) \\
\hline Interlingual Errors (Interference) & 20 & $11 \%$ \\
Intralingual Errors & 166 & $89 \%$ \\
Total & 186 & $100 \%$ \\
\hline
\end{tabular}

From Table 3, it is clearly seen that Intralingual Errors are the highest possible source of errors. Samples of both errors arising from interlingual and intralingual factors are given below.

\section{Interference or Interlingual Errors}

In this source, the errors occurred when the teachers' sentences used the language forms or rules of their first language. They transferred it directly and omitted the well-formed words or phrases of their target language. For example:

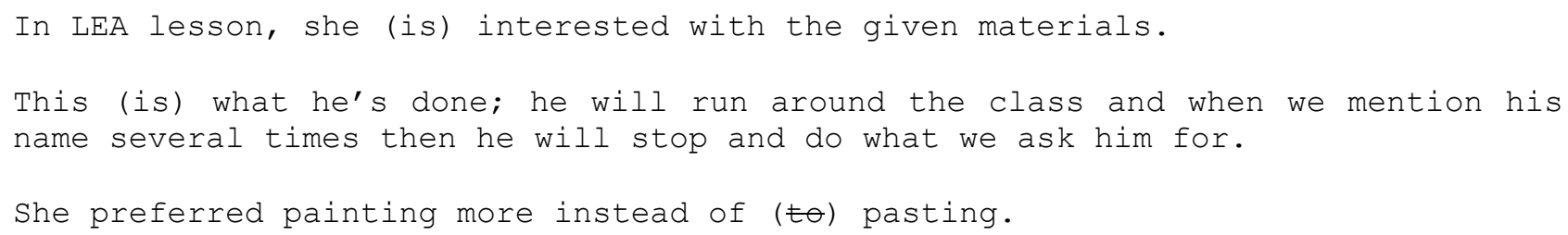


From the example sentences above, for the first and the second sentences, they show that the teacher missed adding 'to be'. It was considered an Interlingual error because they used the form from their first language, Bahasa Indonesia, in which there is no equivalent 'to be' form in its grammar. From the last sentence, the teacher wrote "She preferred painting more instead of to pasting" instead of "She preferred painting to pasting". The teacher used 'more' because she translated from the word 'lebih', unaware that the word 'prefer' (lebih suka) already contains an element of 'more' in it.

\section{Intralingual Errors}

In this source, the errors occurred when the teachers created a deviant structure from the grammar rules. Some teachers also forget to use a well-formed word according to grammar rules. For example:

Before doing a task, she always ask(s) her teacher's guidance.

Kimora needs to be reminded about take (taking) turn and compassion

In the first sentence. the teacher seemed to forget to put an ' $s$ ' after the verb 'ask'. In the second example, the teacher wrote "Kimora needs to be reminded about take turn and compassion" instead of "Kimora needs to be reminded about taking turn and compassion". In this case, the teacher might not know that the phrase which comes after about should be a noun phrase, and so the verb form take should be nominalized as taking.

To confirm the prediction on the source of errors above, three teachers were interviewed using Google form due to the difficulty of meeting up caused by the pandemic. The result of the interview is tabulated in Table 4.

Table 4 Summary of Teachers' Interview Result

\begin{tabular}{|c|c|c|c|c|c|c|}
\hline \multirow[b]{2}{*}{$\begin{array}{c}\text { Sentences } \\
\text { Containing Errors }\end{array}$} & \multirow[b]{2}{*}{ Corrections } & \multicolumn{5}{|c|}{ Possible Source of Errors } \\
\hline & & $\begin{array}{l}\text { Mother- } \\
\text { tongue's } \\
\text { influence }\end{array}$ & $\begin{array}{c}\text { Forgetting } \\
\text { the } \\
\text { grammar } \\
\text { rules }\end{array}$ & $\begin{array}{l}\text { Not } \\
\text { knowing } \\
\text { the } \\
\text { grammar } \\
\text { rules }\end{array}$ & $\begin{array}{c}\text { Careless- } \\
\text { ness }\end{array}$ & $\begin{array}{c}\text { Other } \\
\text { sources } \\
\text { (Please } \\
\text { explain) }\end{array}$ \\
\hline $\begin{array}{l}\text { She preferred to paint } \\
\text { more instead of } \\
\text { pasting. }\end{array}$ & $\begin{array}{lll}\text { She preferred } & \text { to } \\
\text { paint instead } & \text { of } \\
\text { pasting. } & & \end{array}$ & $\sqrt{ }$ & & & & \\
\hline $\begin{array}{l}\text { He is a fast learner } \\
\text { who always trying } \\
\text { (tries) to understand } \\
\text { the lesson in the first } \\
\text { explanation in all } \\
\text { lessons. }\end{array}$ & $\begin{array}{l}\text { He is a fast learner } \\
\text { who always tries to } \\
\text { understand the } \\
\text { lesson in the first } \\
\text { explanation in all } \\
\text { lessons. }\end{array}$ & & $\sqrt{ }$ & & & \\
\hline
\end{tabular}




\begin{tabular}{lll}
\hline Clifford can put joy & Clifford can put joy & I \\
in the middle of & in the middle of \\
simple things such as & simple things such as \\
when he played throw & when he played & usually \\
bean bag and he hits & throw bean bag and \\
one of his favorite he hit one of his & hit \\
words, he is favorite words, he is & several \\
overjoyed of the overjoyed of the & times, so \\
word. & word. & I added \\
[the \\
When the teacher & When the teacher & "s" \\
warns him about & warns him about \\
something he did & something he did & \\
wrong or look(ed) & wrong or looked & \\
wrong to him, he will & wrong to him, he will & \\
stand still and do stand still and do & nothing. \\
nothing. &
\end{tabular}

Table 4 shows that the teachers forget or are ignorant of the grammar rules, indicating intralingual errors. The comment under "Other Sources", in which the teacher admitted that she should add the plural marker ' $\mathrm{s}$ ' since the action is repeated, displayed incorrect application of grammar rule, which also falls under Interlingual Errors.

\section{Discussion}

From the above-mentioned data, it could be seen as a whole that (B1) Syntax - Noun phrase type of error were the biggest total number of errors made by kindergarten teachers. This error occurred because, first, the kindergarten teachers omitted the definite and indefinite articles before a noun in their sentences. As an example of error sentence number (4), the kindergarten teacher wrote "She obeys the teachers and follows activities nicely" instead of "She obeys the teachers and follows the activities nicely". Second, they didn't nominalize the sentence as an example of error sentence number (49) where the kindergarten teacher wrote "Kimora needs to be reminded about take turn and compassion" instead of "Kimora needs to be reminded about taking turn and compassion". Third, they substitute the plurals of singulars in their sentences as shown in the example of error sentence number (27) where the kindergarten teacher wrote "He is also always curious about new thing we learn in the class" instead of "He is also always curious about new things we learn in the class". Fourth, they missed adding pronouns in their sentence as we can see in the example of error sentence number (25) where the kindergarten wrote "We are happy to have Nathan as one of N1 students" instead of "We are happy to have Nathan as one of our N1 students". Lastly, they didn't use suitable prepositions in their sentences as shown in the example of error sentence number (46) where the kindergarten teacher wrote "He shows curiosity about new things we learn at the class" instead of "He shows curiosity about new things we learn in the class".

This result is in line with the previous research done by Puspitasari (2013), who stated that their subjects (college students) also committed mostly syntactical errors in their writing. It means that this category of errors seems to be more challenging than morphological errors. However, this result of the study is different from the previous study done by Mustafa et al. (2016) who stated that the highest error made by their subjects is morphological errors with word forms, which include using wrong parts of speech and employing adjective forms when adverbs were required. Perhaps this difference 
is due to the different age groups of the subjects; Mustafa's subjects are junior high school students, while this study concerns kindergarten teachers. From this, it can be concluded that, although not all the kindergarten teachers come from English Education background, the type of mistakes they commit are typical of those of adult learners, that is, the more 'sophisticated' type of mistakes. Therefore, English training for those teachers can focus on English at intermediate to advanced level, with special focus on syntax and the formation of Noun Phrase. Continuous training and refresher workshop will be needed for the teachers in this study in particular, especially to prevent language "fossilization" (Selinker, 1972 in Wei, 2008) from setting in.

As to the source of errors, it can be seen that the highest possible source of errors is from Intralingual errors with $166(89 \%)$ occurrences. This is in contrast to the finding of $\mathrm{Wu}$ and Garza (2014), who reported that their subjects committed more interlingual than intralingual errors. This might be because the subjects in their study are $6^{\text {th }}$ graders, in contrast to this study's participants who are adults, and therefore are less affected by the influence of the first language.

The interview results further confirmed that the teachers made mistakes mainly due to ignorance or mistaken notion about grammar rules, instead of being influenced by the first language. They admitted that they forget to use the correct grammar rules, do not know the correct grammar, and also sometimes they didn't re-check their works. Hence, the prediction that most of the errors are intralingual in nature seems to be correct.

\section{CONCLUSION}

As part of a community service project aimed at providing custom-made English training to International Kindergarten teachers in Surabaya, Indonesia, this study set out to investigate the type of grammatical (morphological and syntactic) errors found in portfolio reports written by the teachers, and the possible reasons why the errors were committed. This study made use of a document analysis approach, with Error Analysis as the methodology. Nine portfolio reports were examined and the errors found there were categorized based on the Linguistic Category Taxonomy. The possible source of errors was also separated into Interlingual and Intralingual Errors. An interview was also done on selected teachers to further ascertain the cause of errors.

By investigating the percentages of the errors, the most frequent errors made by the kindergarten teacher are errors in syntax, namely Noun phrase formation at $42 \%$, followed by other syntactic errors of Verb phrase formation (31\%), and lastly morphological errors of Third-person singular verb incorrect $(12 \%)$. The writers also found that the most frequent source of errors in the portfolio reports is Intralingual error at $89 \%$, with the remaining being of interlingual type. This is further confirmed by the interview result, which shows that the teachers themselves admitted that they forget or are ignorant of certain grammar rules.

The findings above suggest that the kindergarten teachers committed errors that seem to be typical of adult EFL learners. Hence, English training for those teachers can take this into account, as well as focus on the syntactic and morphological area in which the teachers make mistakes most. It is also further suggested that teacher training colleges consider these problem areas in their English teaching materials. 


\section{REFERENCES}

Abdullah, A. T. H. bin. (2013). Error analysis on the use of the simple tense and the simple past tense in writing essays among TESL College students. International Journal of Education and Research, 1(12), 1-12.

Al-Khresheh, M. H. (2010). Interlingual interference in the english language word order structure of Jordanian EFL learners. European Journal of Social Sciences, 16(1), 105-116.

Arif, N., Ernanda, E., Heryanti, R., \& Volya, D. (2021). Pelatihan Bahasa Inggris untuk guru PAUD Al-Hikmah di kelurahan Mayang Mangurai kota Jambi. Jurnal Karya Abdi Masyarakat, 4(3), 461-467. https://doi.org/10.22437/jkam.v4i3.11563

Burns, A. (2015). Collaborative action research for English language teachers (Issue October). Cambridge University Press.

Corder, S. P. (1973). Introducing Applied Linguistics.

Diani, W. (2018). An error analysis in using subect-verb agreement in the students' paragraph writing at the third semester of English Education Study Program of UIN Raden Intan Lampung in the Academic Year of 2016/2017. Raden Intan State Islamic University.

Dulay, H. (1982). Language Two. Oxford University Press.

Ellis, R. (2005). Analysing Learner Language.

Glen, S. (2016). Statistics How To. https://www.statisticshowto.com/inter-rater-reliability/

Khan, S. R., \& Khan, M. R. (2004). Error analysis in English writing. International Multidisciplinary Research Journal, 2(4), 232-243.

Lieber, R. (2015). Introducing Morphology. In Introducing Morphology. https://doi.org/10.1017/cbo9781316156254

Masruroh, L., Ainiyah, M., \& Hidayah, B. (2018). Pelatihan pengajaran Bahasa Inggris Usia Dini bagi guru-guru Bahasa Inggris di PAUD-TK-MI. JPP IPTEK (Jurnal Pengabdian Dan Penerapan IPTEK), 2(1), 33. https://doi.org/10.31284/j.jpp-iptek.2018.v2i1.247

McMillan, J.H., \& Schumacher, S. (1993). Research in education: A conceptual understanding. New York: Harper Collins.

Mustafa, F., Kirana, M., \& Bahri Ys, S. (2016). Errors in EFL writing by junior high students in Indonesia. International Journal of Research Studies in Language Learning, 5(5). https://doi.org/10.5861/ijrs1l.2016.1366

Politzer, Robert L.; Ramirez, A. G. (1973). Document resume ed 060 146. Research and Development Memorandum No. 103, 1 .

Puspitasari, D. (2013). Grammatical errors made by the second-semester students in writing II subject in the English education department of Yogyakarta State University in the academic year 
of 2012/ 2013. 1-165. https://eprints.uny.ac.id/20520/

Richards, J.C. (1974). Error Analysis. Longman.

Richards, Jack C. (1971). A non-contrastive approach to error analysis. ELT Journal, 25(3), 204-219. https://doi.org/10.1093/elt/XXV.3.204

Rohmah, M. (2011). An analysis of grammatical errors of interrogative sentences made by eighth students of MTS Ma'arif Pare, Kediri. In State institute of Isalamic Studies Sunan Ampel Surabaya. State Institute of Islamic Studies Sunan Ampel Surabaya.

Van Valin Jr., R. D. (2003). An Introduction to Syntax (review). Language, 79(1), 225-225. https://doi.org/10.1353/lan.2003.0098

Wei, X. (2008). The implication of IL Fossilization in Second Language Acquisition. English Language Teaching, 1(1), 127-131. https://doi.org/10.5539/elt.v1n1p127

Wong, R. K. S., \& Russak, S. (2020). Do kindergarten teachers possess adequate knowledge of basic language constructs to teach children to read English as a foreign language? Annals of Dyslexia, 70(1), 79-93. https://doi.org/10.1007/s11881-020-00197-8

Wu, H. P., \& Garza, E. V. (2014). Types and attributes of English writing errors in the EFL contexta study of error analysis. Journal of Language Teaching and Research, 5(6), 1256-1262. https://doi.org/10.4304/jltr.5.6.1256-1262 


\section{APPENDIX 1: SAMPLE OF PORTFOLIO REPORT}

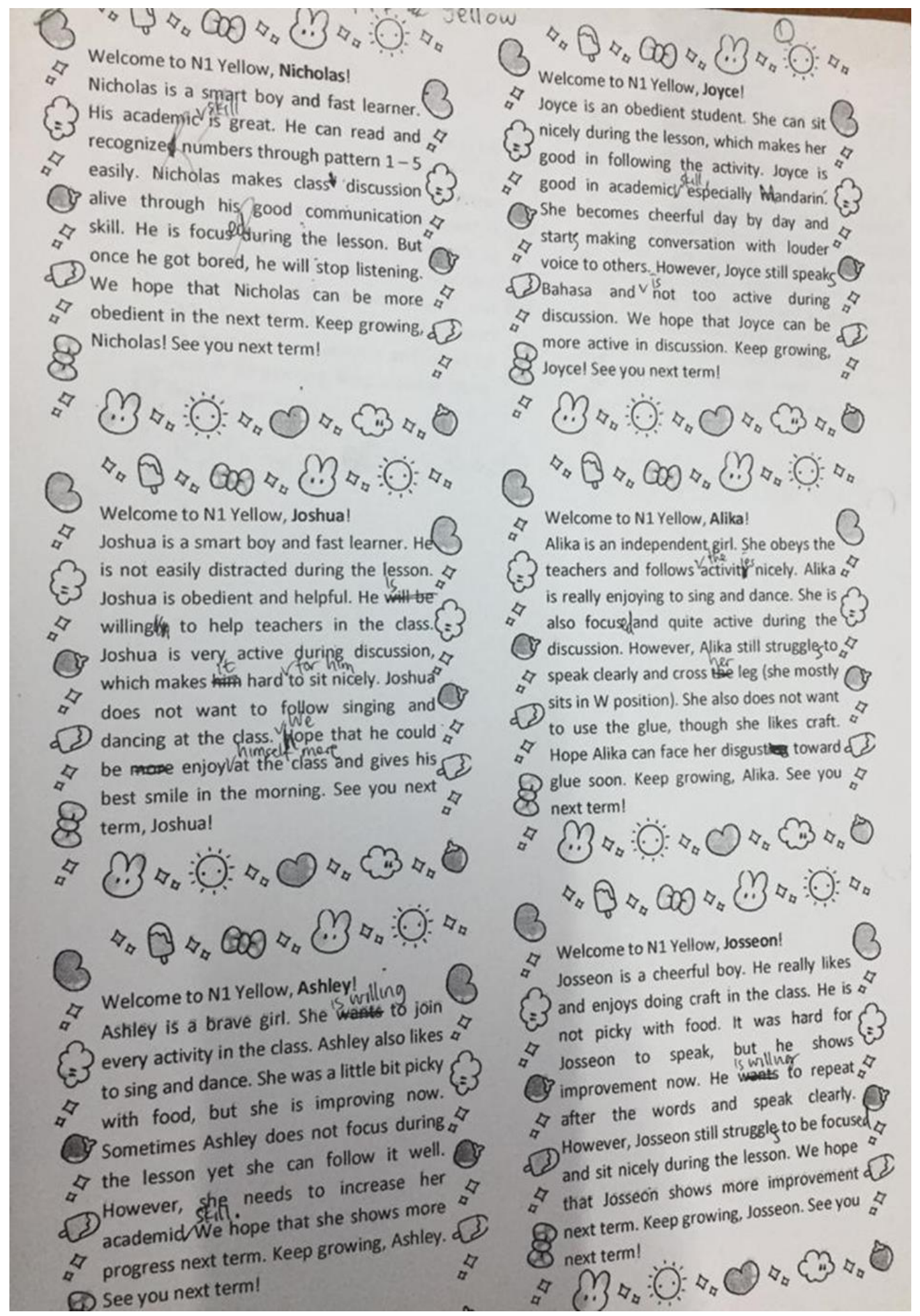

